$$
\text { F }
$$


Brasil e no México. A edição crítica, por Carlos Augusto Calil, do projeto de Blaise Cendrars estudado no artigo "Cinema = Cavação"; um texto de Sergio Miceli sobre Mário de Andrade e resenhas de Álvaro Faleiros e Danielle Corpas completam a presente edição da Revista.

Este número traz ainda um novo projeto gráfico. Nele, as páginas iniciais passam a ser destinadas à divulgação do acervo do IEB, funcionando como um convite à exploração de sua diversidade e potencialidades.

\section{O Editor}

